\title{
Economic analysis of maize production as a function of theorical speed of the tractor-seeder set and the sowing site
}

\author{
Elivânia Maria Sousa Nascimento ${ }^{1 *}$ Carlos Alessandro Chioderoli² Jean Lucas Pereira Oliveira ${ }^{3}$ Marcelo Queiroz \\ Amorim $^{4}$ Isabela Oliveira Lima ${ }^{5}$ \\ 1. State University of Minas Gerais, Ituiutaba, MG, Brazil \\ 2. Federal University of Triângulo Mineiro, Iturama, MG, Brazil \\ 3. Paulista State University Júlio de Mesquita Filho, Jaboticabal, SP, Brazil \\ 4,5. Federal University of Ceará, Fortaleza, CE, Brazil \\ *E-mail of the corresponding author: elivania_sousa@yahoo.com.br
}

\begin{abstract}
Economic feasibility analysis is the fundamental tool in planning any agricultural activity. Thus, the objective of this work was to analyze the economic viability of corn production in the semiarid region of Ceará. The study was carried out in an experimental area at the Federal University of Ceará, Brazil. The experimental design was in randomized blocks, consisting of 3 theoretical speeds $(5.5,6.5$ and $7.5 \mathrm{~km} / \mathrm{h}$ ) and 3 sowing sites (ridges, furrows and conventional), with 5 repetitions. The following were evaluated: operating costs, crop productivity, gross revenue (RB), contribution margin (MC), contribution margin index (BMI) and the cost-benefit ratio (C/B). Operating costs for the installation of 1 ha of corn, second crop 2018/2019, reached R\$3,864.49, the largest disbursement was obtained with supplementary irrigation, received by the crop during the course of the cycle. The L1V2 treatment showed higher average productivity, generating a higher RB (R\$ 5,461.44) and, consequently, a higher MC (R\$ 3,238/ha), as well as a higher BMI (59.29\%). The best C/B ratio was obtained in treatment L3V3 (1.33), being considered viable.
\end{abstract}

Keywords: Operating costs, Productivity, Ridges, Semiarid

DOI: $10.7176 / \mathrm{JESD} / 12-8-09$

Publication date: April $30^{\text {th }} 2021$

\section{Introduction}

Corn (Zea mays L.) is the most produced cereal in the world. Production of 1,120.0 million tons is expected for the 18/19 harvest, world production is basically concentrated in three major producers: USA, China and Brazil; these countries alone represent $65.62 \%$ of world corn production (FAO, 2018).

Brazil is in the third position in the ranking of producers, 101 million tons are expected for the 19/20 harvest, according to data from the United States Department of Agriculture (USDA). Despite being among the three largest producers, Brazil does not stand out among the countries with the highest productivity (Silva \& Silva 2017).

The low average productivity of maize in Brazil does not reflect the good technological level already achieved by most producers turned to commercial crops, since the averages are obtained in the most different regions, in crops with different cultivation systems and purposes (Duarte et al. 2011).

Water unavailability is one of the main factors responsible for the decrease in corn production, reducing growth and development and, consequently, crop productivity (Sales et al. 2016). Directly affecting productivity, water deficiency can reduce the period of grain formation and interfere with the development of the ovaries, increasing the number of aborted grains (Marwein et al. 2017).

To ensure the productivity of the corn, it is necessary to consider not only the genetic technology of the hybrids and the soil tillage system, but also the efficiency of the machines and implements that are being used in the tillage and other operations involved in the process productive, such as sowing (Almeida et al. 2010).

Sowing is one of the main mechanized agricultural operations in the context of modernization of agriculture, and can be carried out on the plane, in furrows, in ridges or pits, and the distribution of seeds is associated with the type of culture, the conditions of humidity and temperature, which are key tools in productivity. Without the harmony of these requirements, agricultural activity may become impracticable (Balastreire 2010).

The formation of ridges in agricultural areas is common, however, their formation may have different objectives 
depending on the region or location. In regions with water scarcity, such as northeastern Brazil, construction can be carried out to capture rainwater and conserve soil. In soils with drainage problems and floodplain areas, they are built for water drainage and soil aeration.

The knowledge of production costs in a rural property makes it possible to verify the profitability, profitability and efficiency of the production system adopted by the rural producer (Richetti 2016). Corn prices follow supply movements, establishing fluctuations according to the harvest and off-season periods (Silva et al. 2007). The application of a specific technology directly affects production costs and determines crop productivity (Rodrigues et al. 2018).

Feasibility analysis is an important tool for planning any agricultural activity, therefore, whenever the rural producer plans to harvest crops, he must be concerned with the production processes and be attentive to the managerial and administrative actions of the property, as well as to market fluctuations for the time to commercialize the results obtained by the crop.

In this sense, to assist the producer in determining and evaluating the economic results that can be obtained in the properties, the objective of this work was to analyze the economic viability for the corn crop according to the sowing place and theoretical speed of the mechanized set tractor-seeder in the semiarid region of Ceará.

\section{Material and methods}

The study was conducted in an experimental area at the Federal University of Ceará, located in the city of Fortaleza, State of Ceará, located at the geographical coordinates of $03^{\circ} 43^{\prime} \mathrm{S}$ and $38^{\circ} 32^{\prime} \mathrm{W}$, at $19 \mathrm{~m}$ altitude. The climate of the region is of the Aw 'type, being it tropical rainy, very hot, with predominance of rains in the summer and autumn seasons according to Koppen's classification (Alvares et al. 2014).

The area's soil was classified as Red Yellow (Embrapa 2013). Before the installation of this experiment, physical and chemical characterization of the soil was carried out in the $0-0.15$ and $0.15-0.30 \mathrm{~m}$ layers according to Embrapa's methodology (2011). The results were: soil density $=1.44$ and $1.45 \mathrm{~g} \mathrm{g.cm}-3$, macroporosity $=0.09$ and $0.06 \mathrm{~m}^{3} / \mathrm{m}^{3}$, microporosity $=0.15$ and $0.13 \mathrm{~m}^{3} / \mathrm{m}^{3}$, total porosity $=0.24$ and $0.19 \mathrm{~m}^{3} / \mathrm{m}^{3}, \mathrm{Ca}^{2+}=3$ and $13 \mathrm{mmol}_{\mathrm{c}} / \mathrm{dm}^{3}$, $\mathrm{Mg}^{2+}=12$ and $8 \mathrm{mmol}_{\mathrm{c}} / \mathrm{dm}^{3}, \mathrm{Na}^{+}=12$ and $10 \mathrm{mmol}_{\mathrm{c}} / \mathrm{dm}^{3}, \mathrm{~K}^{+}=18$ and $16 \mathrm{mmol}_{\mathrm{c}} \cdot \mathrm{dm}^{3}, \mathrm{H}^{+}+\mathrm{Al}^{3+}=14.9$ and 18.9 mmol $\mathrm{dm}^{3}, \mathrm{Al}^{+}=0$ and 0 mmolc. $\mathrm{dm}^{3}$ and textural class = sandy loam, respectively, at the depths of $0-0.15$ and 0.15-0.30 m.

The experimental design was in randomized blocks consisting of nine treatments, being, three sowing sites (L1 ridge, L2 - furrow and L3 - conventional) and three theoretical speeds (V1 - 5.5, V2 - 6.5 and V3 - 7.5 km/h), with 5 repetitions. The experimental plot consisted of 3 rows 20 meters long, with a spacing of $0.90 \mathrm{~m}$ between them. The useful area for data evaluation corresponded to the central 10 meters of the central line.

Prior to sowing, the soil was prepared conventionally using a plow and harrow at a depth of $0.20 \mathrm{~m}$. For sowing, a BM 120 4x2 TDA (Auxiliary Front Traction) tractor was used, with $88.26 \mathrm{~kW}(120 \mathrm{hp})$ of engine power, at a speed of 2,000 rpm, pulling a pneumatic precision seed drill-model JMJ2090 mounted, configured with 3 rows, spaced at $0.90 \mathrm{~m}, 39 \mathrm{~L}$ fertilizer and seed reservoir capacity, with deposits filled at $80 \%$ of capacity over sowing.

For sowing in the ridges, the sowing machine was equipped with furrowers with a length of $0.50 \mathrm{~m}$ and a height of $0.25 \mathrm{~m}$. The corn seed used in the experiment was the cultivar Al Avaré, considered to be of high technology, purity of $98 \%$ and survival of $85 \%$, targeting a population of 66,666 plants $/$ ha, with sowing density of 6 seeds $/ \mathrm{m}$.

During the conduction of the corn crop, base and cover fertilizations were carried out, based on the chemical analysis of the soil; in the basic fertilization $250 \mathrm{~kg} /$ ha of fertilizer was used in the commercial formulation of NPK 10-28-20. The top-dressing fertilizations were carried out in the V2, V4 and V8 stages of corn, using $300 \mathrm{~kg} / \mathrm{ha}$ of urea and $120 \mathrm{~kg} / \mathrm{ha}$ of potassium chloride.

To control the presence of the cartridge caterpillar (Spodoptera frugiperda), four applications of the commercial product Lufenuron were applied at a dose of $18 \mathrm{~g} / \mathrm{ha}$ and Lannat BR, phosphorus insecticide, in stages V4, V8, V12 and R1. Two applications of Glyphosate herbicide were used to control weeds, at the concentration of 0.025 $\mathrm{L}$ of commercial product per L of syrup.

The harvest was carried out manually within the useful area of each plot, with the ears being mechanically tracked. The data were corrected for $13 \%$ of wet basis and transformed into $\mathrm{kg} / \mathrm{ha}$ of grains, based on the Seed Analysis Rules (Brasil, 2009).

For the composition and analysis of operating costs, the methodology proposed by Pacheco (2000) was used. In this methodology, the operating cost of agricultural machinery (CT) is normally divided into fixed costs (CF) and 
variable costs $(\mathrm{CV})$. Fixed costs include depreciation, interest and shelter and insurance fees. Variable costs include labor and maintenance: fuel consumption, lubricant, maintenance fee.

Depreciation was calculated using the straight-line method, where the scrap value is arbitrated at $10 \%$ of the machine's acquisition value, calculated according to Equation (1).

$$
D=\frac{V i-0,1 V i}{V u}
$$

On what: D - depreciation (R\$/h), Vi - machine purchase price (R\$), Vu - lifespan (h).

Interest was calculated on the acquisition value of the capital asset over its useful life, according to the Equation (2).

$$
J=\left(\frac{V i \times 0,1 V i}{2}\right) \times i
$$

On what: $\mathrm{J}$ - interest $(\mathrm{R} \$ / \mathrm{h}), \mathrm{i}$ - interest rate per year (decimal).

The coast of shelter and insurance $(\mathrm{A} / \mathrm{S})$ expressed in $\mathrm{R} \$ / \mathrm{h}$ was calculed according to Equation (3), where a value of $3 \%$ of the acquisition value is attributed.

$$
A S=0,03 x V i
$$

According to ASAE, the average fuel consumption in agricultural machinery is estimated as a function of power. Fuel consumption varies according to the type of engine and the power developed in the operation, being determined by Equation (4).

$$
C=0,15 \times \text { Pbt } \times \text { Pcomb }
$$

On what: $\mathrm{C}$ - fuel consumption $(\mathrm{R} \$ / \mathrm{h}), \mathrm{Pbt}$ - drawbar power (cv), Pcomb - fuel price (R\$/L), The amount of lubrificants sped per hour can be obtained as Equation (5).

$$
L=\left(4,3 \times 10^{-4}\right) x(\text { Pnom } x \text { 0,02169) } x \text { Póleo }
$$

On what: $\mathrm{L}$ - lubrificants consumption $(\mathrm{R} \$ / \mathrm{h})$, Pnom - rated power $(\mathrm{cv})$, Poil - oil price $(\mathrm{R} \$ / \mathrm{L})$

To calculate the cost of maintenance, the following criteria were adopted: For the tractor, an amount equal to $100 \%$ of the initial investment during its useful life is estimated and for the implement, an annual rate of 4 to $6 \%$ per year is estimated, on initial investment (Equation 6).

$$
M=\left(V i x\left(\frac{100}{V u}\right)\right)
$$

On what: $\mathrm{M}$ - maintenance $(\mathrm{R} \$ \mathrm{~h}), \mathrm{Vi}$ - initial value $(\mathrm{R} \$), \mathrm{Vu}$ - lifespan (years).

The cost of labor includes the operator's salary and social charges. For social charges, a value between 66 and $80 \%$ of the operator's salary is adopted, which can be obtained from Equations (7), (8) and (9).

$$
\begin{gathered}
S M=2 \times \text { Basic salary } \\
E S=66 \% \times \text { Monthly salary } \\
M O=\frac{S M+E S}{176}
\end{gathered}
$$

On what: SM - monthly salary (R\$), ES - social charges (R\$), MO - manpower (R\$/h).

The variable costs of cultivation by sowing modality were estimated from the technical coefficients (inputs and operations) recorded in the experiment and extrapolated to 1 ha, according to local commercial data. The costs of operations and inputs were calculated in $\mathrm{R} \$ /$ ha, equivalent to the month of March 2018. For the calculation of the contribution margin, gross revenue from the sale of corn fewer operating costs with inputs and operations as Equation (10).

$$
M C=(R B-(C V+D V)
$$

On what: $\mathrm{MC}$ - contribution margin $(\mathrm{R} \$), \mathrm{RB}$ - gross revenue $(\mathrm{R} \$), \mathrm{CV}$ - variable coats $(\mathrm{R} \$), \mathrm{DV}$ - variable expenses $(\mathrm{R} \$)$.

The contribution margin index (IMC) was calculated by the relationship between the contribution margin and gross revenue (Equation 11).

$$
I M C=\frac{M C}{R B} X 100
$$


The cost/benefit ratio $(\mathrm{RCB})$ was obtained by the relationship between operating costs and gross revenue (Equation 12).

$$
R C B=\frac{C T}{R B}
$$

The data were subjected to analysis of variance by the $\mathrm{F}$ test and the means, when significant, were compared by the Tukey test at $5 \%$ significance.

\section{Results and discussion}

Operating costs for installing one hectare of corn second crop 2018/2019 reached R $\$ 3,864.49$, with the largest disbursements being in relation to crop irrigation, which contributed to the increase in costs of agricultural operations (Table 1). Spending on irrigation occurred due to the characteristics of the region's climate and soil, as it cannot store enough water in the soil to supply the crop's water needs. This result disagrees with that found by Richetti (2018), who observed an increase in costs due to spending on seeds and fertilizers, due to the requirement of the corn crop, demanding a large amount for high yields.

Table 1. Cost component for economic analysis of maize culture during the experiment

\begin{tabular}{|l|l|l|l|l|}
\hline Coast components & Unity & Amount & Unitary value & Total value \\
\hline Inputs & & & & $1,641.63$ \\
\hline Planting fertilizers & $\mathrm{kg}$ & 400 & 1.4 & 560 \\
\hline Potassium chloride & $\mathrm{kg}$ & 120 & 2 & 240 \\
\hline Urea & $\mathrm{kg}$ & 311 & 1.8 & 559.8 \\
\hline Corn seeds & $\mathrm{Seeds} / \mathrm{bag}$ & 66.666 & 120 & 133.332 \\
\hline Glyphosate herbicide & $\mathrm{L}$ & 3 & 32 & 96 \\
\hline Lanatte insecticide & $\mathrm{L}$ & 1,5 & 35 & 52.5 \\
\hline Agricultural operations & & & & $2,222.86$ \\
\hline Herbicide application & $\mathrm{HM}$ & 2 & 16.8 & 33.6 \\
\hline Corn sowing & $\mathrm{HM}$ & 1 & 94.26 & 94.26 \\
\hline Cover fertilization & $\mathrm{HM}$ & 2 & 41.7 & 83.4 \\
\hline Inseticide application & $\mathrm{HM}$ & 2 & 16.8 & 33.6 \\
\hline Irrigation & $\mathrm{mm}$ & 230 & 7.60 & $1,748.00$ \\
\hline Harvest & $\mathrm{HM}$ & 1 & 130 & 130 \\
\hline Transport/unloading & $\mathrm{HM}$ & 1 & 100 & 100 \\
\hline Total coast (R\$) & & & & $3,864.49$ \\
\hline Source: & & & & \\
\hline
\end{tabular}

Source: prepared by the authors. Methodology proposed by Pacheco (2000); 1 bag - 60.000 seeds, HMmachine-hour.

Considering the economic results of corn, analysis of variance was used in order to ascertain significant differences between the arithmetic means of the two factors: theoretical speed of the mechanized tractor-seeder-fertilizer set and sowing location (Table 2). The treatments had no significant effect, at 5\% significance, by the F test. 
Table 2. Summary of Analysis of Variance for the economic performance of corn during the experiment as a function of the evaluated treatments

\begin{tabular}{|c|c|c|c|c|c|}
\hline $\begin{array}{ll}\text { Causes } & \text { of } \\
\text { variation } & \end{array}$ & $\begin{array}{l}\text { Degree of } \\
\text { freedom }\end{array}$ & Sum of squares & Medium squares & F test & p Value \\
\hline \multicolumn{6}{|l|}{ Productivity (kg/ha) } \\
\hline \begin{tabular}{l|l} 
Treatment & \\
\end{tabular} & 8 & 13685891.20 & 1710736.45 & $710.92^{* *}$ & $<0.0001$ \\
\hline Residue & 36 & 86629.20 & 2406.36 & & \\
\hline Total & 44 & 13772520.80 & & & \\
\hline \multicolumn{6}{|c|}{ Gross revenue $(\mathbf{R} \$)$ * } \\
\hline \begin{tabular}{l|l} 
Treatment & \\
\end{tabular} & 8 & 35035882.49 & 4379485.31 & $710.92^{* *}$ & $<0.0001$ \\
\hline Residue & 36 & 221770.75 & 6160.29 & & \\
\hline Total & 44 & 35257653.24 & & & \\
\hline \multicolumn{6}{|c|}{ Contribution margin (R\$) } \\
\hline Treatment & 8 & 35035882.49 & 4379485.31 & $710.92^{* *}$ & $<0.0001$ \\
\hline Residue & 36 & 221770.75 & 6160.29 & & \\
\hline Total & 44 & 35257653.24 & & & \\
\hline \multicolumn{6}{|c|}{ Contribution margin index $(\%)$} \\
\hline Treatment & 8 & 6653.81 & 831.72 & $469.90^{* *}$ & $<0.0001$ \\
\hline Residue & 36 & 63.71 & 1.76 & & \\
\hline Total & 44 & 6717.53 & & & \\
\hline \multicolumn{6}{|l|}{ Cost-benefit ratio } \\
\hline Treatment & 8 & 2.011 & 0.25 & $469.90^{* *}$ & $<0.0001$ \\
\hline Residue & 36 & 0.019 & 0.0005 & & \\
\hline Total & 44 & 2.03 & & & \\
\hline
\end{tabular}

Source: prepared by the authors. * Significant at $5 \%$ by the test F; ** Significant at $1 \%$ significance, by the test $\mathrm{F}$; NS is not significant at $5 \%$ significance, by the $\mathrm{F}$ test.

All evaluated treatments showed average productivity higher than those found for the State of Ceará in the $2018 / 2019$ harvest for the second harvest corn, which was $792 \mathrm{~kg} / \mathrm{ha}$ and in the 2019/2020 harvest, $834 \mathrm{~kg} / \mathrm{ha}$, according to data from Conab (2018) (Table 3). The L1V2 treatment (sowing on top of the ridge at a speed of 6.5 $\mathrm{km} / \mathrm{h}$ ) showed higher average productivity, generating greater gross revenue ( $\mathrm{R} \$ 5,461.44)$, consequently, greater contribution margin ( $\mathrm{R} \$ 3,238 / \mathrm{ha})$, as well as a higher BMI (59.29\%), not differing from treatments (L1V1 and L1V3), that is, the contribution margin represents $59.29 \%$ of the operational costs with inputs and operations. The cost-benefit ratio was less than 1 , that is, the costs were higher than the benefits, making this treatment unfeasible. 
Table 3. Average values for economic performance for each combination of sowing location and speed

\begin{tabular}{|l|l|l|l|l|l|}
\hline Treatments & $\begin{array}{l}\text { Productivity } \\
\mathbf{( k g / h a )}\end{array}$ & $\begin{array}{l}\text { Gross } \\
\text { revenue } \\
\mathbf{( R \$ )}\end{array}$ & $\begin{array}{l}\text { Contribution } \\
\text { margin } \\
\mathbf{( R \$ )}\end{array}$ & $\begin{array}{l}\text { Contribution } \\
\text { margin index } \\
\mathbf{( \% )}\end{array}$ & $\begin{array}{l}\text { Coast- } \\
\text { benefit ratio } \\
\text { (C/B) }\end{array}$ \\
\hline L1V1 & $3,279 \mathrm{~b}$ & $5,247.04 \mathrm{~b}$ & $3,024.18 \mathrm{~b}$ & $57.60 \mathrm{a}$ & $0.73 \mathrm{f}$ \\
\hline L1V2 & $3,413 \mathrm{a}$ & $5,461.44 \mathrm{a}$ & $3,238.58 \mathrm{a}$ & $59.29 \mathrm{a}$ & $0.73 \mathrm{f}$ \\
\hline L1V3 & $3,304 \mathrm{~b}$ & $5,286.40 \mathrm{~b}$ & $3,063.54 \mathrm{~b}$ & $57.95 \mathrm{a}$ & $0.70 \mathrm{f}$ \\
\hline L2V1 & $2,511 \mathrm{e}$ & $4,017.60 \mathrm{e}$ & $1,794.74 \mathrm{e}$ & $44.67 \mathrm{c}$ & $0.96 \mathrm{~d}$ \\
\hline L2V2 & $2,766 \mathrm{c}$ & $4,426.24 \mathrm{c}$ & $2,203.38 \mathrm{c}$ & $49.77 \mathrm{~b}$ & $0.87 \mathrm{e}$ \\
\hline L2V3 & $2,635 \mathrm{~d}$ & $4,216.64 \mathrm{~d}$ & $1,993.78 \mathrm{~d}$ & $28.53 \mathrm{e}$ & $0.91 \mathrm{de}$ \\
\hline L3V1 & $1,944 \mathrm{~g}$ & $3,111.36 \mathrm{~g}$ & $888.50 \mathrm{~g}$ & $28.53 \mathrm{e}$ & $1.24 \mathrm{~b}$ \\
\hline L3V2 & $2,349 \mathrm{f}$ & $3,759.04 \mathrm{e}$ & $1536.18 \mathrm{f}$ & $40.82 \mathrm{~d}$ & $1.02 \mathrm{c}$ \\
\hline L3V3 & $1,806 \mathrm{~h}$ & $2,889.60 \mathrm{~h}$ & $666.74 \mathrm{~h}$ & $22.97 \mathrm{f}$ & $1.33 \mathrm{a}$ \\
\hline DMS (5\%) & 102.26 & 163.66 & 163.66 & 2.77 & 0.04 \\
\hline CV (\%) & 1.83 & 1.83 & 3.83 & 2.92 & 2.43 \\
\hline $\begin{array}{l}\text { Overall } \\
\text { average }\end{array}$ & 2,667 & 4,268 & 2,045 & 45.43 & 0.94 \\
\hline Soure: Elabo & & & & \\
\hline
\end{tabular}

Source: Elaborated by the authors. * Average selling price of $\mathrm{kg}$ of corn - R\$ 1,60 kg (Ceará State Supply Center); IMC: Contribution Margin Index; C/B: Coast-Benefit; L1- seeding on top of the ridge; L2 - sowing in the furrow, L3 - conventional, VT1 - 5,5 km.h ${ }^{-1}$; VT2- 6,5 km.h ${ }^{-1}$; VT3 - 7,5 km.h-1. Averages fallowed by the same letter differ at the $5 \%$ probability level.

The higher productivity, L1V2, can also be attributed to the mobilization of the soil for the formation of ridges. As a result, the root growth of the crop was facilitated and became closer to the surface, where water and nutrients were made available. Water may have served as a means by which mineral nutrients moved from the soil solution to the plant's roots (Gessler et al. 2017), contributing to the increase in productivity in this treatment. Table 3 also shows that the best value for money $(\mathrm{C} / \mathrm{B}>1)$ was obtained with L3V3 treatment (conventional seeding and speed of $7.5 \mathrm{~km} / \mathrm{h}$ ), which was 1,33 , that is, for each unit invested the return was $\mathrm{R} \$ 0.33$, being considered viable, indicating that the revenue was greater than the cost to produce according to Vitale \& Miranda (2010). However, this treatment showed the lowest grain yield $(\mathrm{R} \$ 1,806 \mathrm{~kg} / \mathrm{ha})$, consequently, the lowest gross revenue ( $R \$ 2,889.60)$. Such aspects reinforce the importance of the sowing place and the speed of the mechanized set, in order to achieve greater crop productivity and good profitability for the producer.

Observing the results obtained in this work and the characteristics of the region, the use of irrigation to supply the need for corn culture was assertive, since water deficiency can limit the functioning of plant activities, among them, reduction absorption and accumulation of nutrients (Hu \& Schmidhaler 2005). The total water depth required for each crop must also meet the water requirements of plants throughout their development cycle, which varies from one period to the next, due to the greater evapotranspiration (Kopp et al. 2015). The experiment was carried out in the period corresponding to the second harvest in the state, that is, the period in which there is little rain, and the incidence of sunlight is very intense. The good results found in this work can also be related to the interception of solar radiation by the leaves of corn plants, which directly influences grain yield (Uate 2016).

The results of this study highlight the importance of carrying out the economic analysis of productive systems, in addition to the technical or visual analysis, since the reliability of the data allows a possible use of the evaluated techniques, under conditions of production similar systems to those developed for the experiment.

\section{Conclusion}

The economic indicators showed satisfactory values, as the cultivation of second crop corn proved to be economically viable for the property under study. The use of irrigation was a determining factor in production costs, but the use in the conditions of the study was positive. Further studies are needed to demonstrate the influence of the sowing location and theoretical speed of the mechanized set on corn productivity. 


\section{References}

Almeida R. A. S., Tavares-Silva, C. A., \& Silva, S. L. (2010). Energy perfomance of an entire tractor-seeder according to the escalation of marches and engine speeds. Agrarian, 3, 63-70

Alvares, C. A. et al. (2013). Köppen's climate classification map for Brazil. Meteorolgische Zeitschrift, 22, 711 728. doi:10.1127/0941-2948/2013/0507, https://doi.org/10.1127/0941-2948/2013/0507

Balastreire L. A. (2010). Máquinas Agrícolas. Sao Paulo: Manole

Brasil. (2009). Ministério da Agricultura, Pecuária e Abastecimento. Regras para análise de sementes. Secretaria de Defesa Agropecuária. Brasília: Mapa/ACS. Available: https://www.gov.br/agricultura/ptbr/assuntos/insumos-agropecuarios/arquivos-publicacoes-insumos/2946_regras_analise_sementes.pdf (May 7, 2019)

Companhia Nacional de Abastecimento Brasileiro. (2018). Acompanhamento da safra Brasileira de graõs. v.05, safra 2017/18, nono levantamento. Available: https://www.conab.gv (October 12, 2020)

Duarte J.O., Garcia J. C., \& Miranda R.A (2011). Sistema de Produção: Cultivo do Milho. Available: http://sistemasdeproducao.cnptia.embrapa.br/FontesHTML/Milho/CultivodoMilho 7 ed/economia.htm (November 11, 2019)

Empresa Brasileira de Pesquisa Brasileira (2011). Manual de métodos de análise de solos. Rio de Janeiro: Embrapa Solos.

https://www.agencia.cnptia.embrapa.br/Repositorio/Manual+de+Metodos_000fzvhotqk02wx5ok0q43a0 ram31wtr.pdf (October 2, 2019)

Empresa Brasileira de Pesquisa Brasileira. (2013). Sistema Brasileiro de Classificação de Solos. Brasília: Embrapa Solos. Available: http://livimagens.sct.embrapa.br/amostras/00053080.pdf. (October 2, 2019)

Food and Agriculture Organization of the United Nations. (2018). Crops. Available: http://www.fao.org/faostat/en/\#search/crop (May 12, 2019)

Gessler, A., Schaub, M., \& Mcdowell, N. G. (2017). The role of nutrientes in drought-induced tree mortality and recovery. New Phytologist, 214, 513-520

Hu, Y., \& Schmidhalter, U. (2005). Drought and salinity: A comparison of their effects on mineral nutrition of plants. Journal of Plant Nutrition and Soil Science, 168, 541-549

Instituto Brasileiro de Geografia e Estatística. (2006). Censo Demográfico. Available: http://www.ibge.gov. br (May 5, 2019)

Köpp, L. M. et al. (2015). Simulation of water requirement and estimation of productivity for maize in cities of Rio Grande do Sul. Revista Brasileira de Milho e Sorgo, 14, 235-246. doi: 10.18512/19806477/rbms.v14n2p235-246, http://dx.doi.org/10.18512/1980-6477/rbms.v14n2p235-246

Marwein, M. A. et al. (2017). Response of water deficit regime and soil amelioration on evapotranspiration loss and water use efficiency of maize (Zea mays L..) in subtropical northeastern Himalayas. Internacional Journal of Biometereology, 61, 845-855. doi: 10.1007/s00484-016-1262-4, https://link.springer.com/article/10.1007/s00484-016-1262-4

Pacheco, E. P. (2000). Seleção e custo operacional de máquinas agrícolas. Rio Branco: Embrapa Acre.

Richetti, A. (2016). Viabilidade econômica da cultura da soja na safra 2016/2017, em Mato Grosso do Sul. Embrapa Agropecuária. https://ainfo.cnptia.embrapa.br/digital/bitstream/item/146045/1/COT2016211.pdf (April 11, 2019)

Richetti, A. (2018). Viabilidade Econômica da Cultura do Milho Safrinha 2018, em Mato Grosso do Sul. Dourados, MS.

Available: https://www.infoteca.cnptia.embrapa.br/infoteca/bitstream/doc/1087320/1/Comunicado231.pdf (April $11,2019)$

Rodrigues, C. C. et al. (2018). Economic and financial analysis of the deployment of the cultivation of green corn. Agrarian Academy, 5, 19-29. Available: http://www.alice.cnptia.embrapa.br/alice/handle/doc/1090641) (April $11,2019)$

Sales, R. A. et al. (2016). Estimated needs water maize in the edafoclimatic conditions of São Mateus -ES. Enciclopédia Biosfera, 13, 598-609. doi: 10.18677/Enciclopedia_Biosfera_2016_053, http://www.conhecer.org.br/enciclop/2016a/agrarias/estimativa.pdf

Silva, E. C. et al. (2007). Economics analysis of nitrogen fertilizer in the crop under no-tillage in sucession to cover in Red Latossol Nitrogen. Acta Scientiarum, 29, 445-452. doi:10.4025/actasciagron.v29i4.395, https://doi.org/10.4025/actasciagron.v29i4.395

Silva, B. E. C., \& Silva, M. R. J. (2017). Economic and Financial viability of the implementation of corn culture 
in the municipality of Santa Teresa-ES. Unipan, 23, 17-25

Uate, J.V. (2016), "Genetic progress and adaptability and stability of corn cultivars evaluated in cultivation and use value tests", $\mathrm{PhD}$ thesis, Federal University of Lavras, MG, Brazil

Vitale, V., \& Miranda, G. de M. (2010). Comparative analysis of the economic viability of Pinus taeda and Eucalyptus dunnii plantations in the south center region of Parana State, Brazil. Floresta, 40, 469-476 